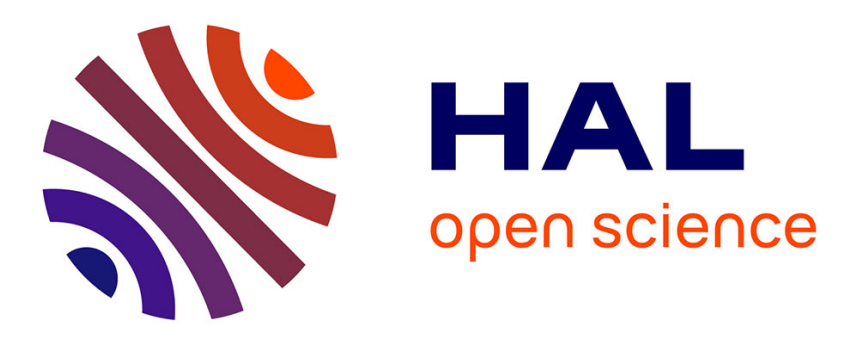

\title{
Prostaglandin EP2 and EP4 receptors modulate CCL2 (MCP-1) expression in response to LPS-induced renal glomerular inflammation
}

Gunther Zahner, Melanie Schaper, Ulf Panzer, Malte Andreas Kluger, Rolf A.K. Stahl, Friedrich Thaiss, André Schneider

\section{To cite this version:}

Gunther Zahner, Melanie Schaper, Ulf Panzer, Malte Andreas Kluger, Rolf A.K. Stahl, et al.. Prostaglandin EP2 and EP4 receptors modulate CCL2 (MCP-1) expression in response to LPS-induced renal glomerular inflammation. Biochemical Journal, 2009, 422 (3), pp.563-570. 10.1042/BJ20090420 . hal-00479174

\section{HAL Id: hal-00479174 https://hal.science/hal-00479174}

Submitted on 30 Apr 2010

HAL is a multi-disciplinary open access archive for the deposit and dissemination of scientific research documents, whether they are published or not. The documents may come from teaching and research institutions in France or abroad, or from public or private research centers.
L'archive ouverte pluridisciplinaire HAL, est destinée au dépôt et à la diffusion de documents scientifiques de niveau recherche, publiés ou non, émanant des établissements d'enseignement et de recherche français ou étrangers, des laboratoires publics ou privés. 


\section{Prostaglandin EP2 and EP4 receptors modulate CCL2 (MCP-1) expression in response to LPS-induced renal glomerular inflammation}

Gunther Zahner, Melanie Schaper, Ulf Panzer, Malte Kluger, Rolf A.K. Stahl, Friedrich Thaiss and André Schneider

Zentrum Innere Medizin, III. Medizinische Klinik, Universitätsklinikum Hamburg Eppendorf, Hamburg, Germany

Running title: EP receptors modulate CCL2 expression

\section{Corresponding author:}

Gunther Zahner, Ph.D.

Universitätsklinikum Hamburg Eppendorf

Zentrum Innere Medizin

III. Medizinische Klinik

Martinistr. 52

20246 Hamburg

Germany

Phone: +49-40-7410-53936

Fax: +49-40-7410-59036

E-mail: zahner@uke.uni-hamburg.de 


\section{SUMMARY}

The pro-inflammatory chemokine CCL2 (MCP-1) is upregulated in the glomerular compartment during the early phase of LPS-induced nephritis. This upregulation also appears in cultured mesangial cells (MC) and is more pronounced in MC lacking the prostaglandin EP2 receptor or in MC treated with a prostaglandin EP4 receptor antagonist. To examine a possible feedback of EP receptor stimulation on CCL2 expression, we chose an in vitro model in MC with down regulated EP receptor expression. By selective overexpression of EP receptors in these cells, their effects on LPS-induced CCL2 expression were examined.

Cells were stimulated with LPS and CCL2 gene expression was examined and compared to LPS stimulated, mock transfected COX-2+ cells. Overexpression of EP1 as well as EP3 had no effect on LPS induced CCL2 mRNA expression. In contrast, overexpression of EP2 as well as EP4 receptors significantly decreased LPS-induced CCL2 expression.

These results support the hypothesis that COX-2 derived prostaglandins, when strongly induced, counter-balanced inflammatory processes through EP2 and EP4 receptors in MC.

Keywords: Cyclooxygenase 2, mesangial cells, LPS, EP receptor 


\section{INTRODUCTION}

Prostaglandin E2 (PGE2) is an important arachidonic acid metabolite generated by sequential action of cyclooxygenase and prostaglandin E synthase [1 - 3]. Pro-inflammatory agents such as interleukin $1 ß$ [4] and lipopolysaccharide (LPS) [5], a cell wall component of gram-negative bacteria, rapidly induce PGE2 by Cyclooxygenase-2 (COX-2). Thus, COX-2 generated PGE2 plays an important role in early inflammatory processes including diseases associated with inflammation such as rheumatoid arthritis [6] and different forms of glomerulonephritis [7 - 9].

In immune-mediated glomerulonephritis, PGEs improve structural damage through reduction of glomerular immune complex formation as well as reduction of inflammatory cell infiltration [10 - 11] and deposition of extracellular matrix products [12].

The physiological effects of PGE2 are mediated through prostaglandin E receptors (EP receptors). Four EP receptors (EP1 to EP4) are currently known. They are G-protein coupled seven transmembrane spanning receptors with a strong heterogenicity in respect to the underlying signal transduction pathways. The EP1 receptor is linked to stimulation of intracellular calcium $[13,14]$. The EP3 receptor exists in multiple splice variants that show different activation patterns. First, Sugimoto et al. demonstrated an EP3 mediated inhibition of cAMP through activating a $G_{i}$ protein [15]. Later studies demonstrated that other splice variants are coupled to stimulation of cAMP [16] or $\mathrm{IP}_{3}$ [17]. The EP2 receptor is coupled to a Gs protein leading to stimulation of cAMP formation [18, 19]. The EP4 receptor is also coupled to Gs, but cAMP formation is weaker compared to EP2 activation. In addition, the EP4 receptor is capable to activate the PI3 kinase dependent pathway leading to activation of erk1/2 [20, 21]. Thus, PGE2 may lead to different intracellular responses depending on the specific distribution of the different EP receptors on a particular cell type. Through cellspecific EP receptor distribution, PGE2 may exert different roles with a complex pattern of pro- [22] as well as anti-inflammatory [23] effects in the immune system.

CCL2 (MCP-1), a pro-inflammatory chemokine of the C-C group, is highly expressed in glomeruli under pathophysiologic conditions associated with glomerular infiltration of monocytes/macrophages [24 - 26]. Cyclooxygenase metabolites, especially PGEs, reduce glomerular CCL2 expression and thus ameliorate monocyte/macrophage influx in glomerulonephritis [27, 28]. Mesangial cells (MC) that constitute a major part of the glomerular structure and are located between the glomerular capillaries [29] produce CCL2 in response to diverse inflammatory stimuli [30 - 32]. Therefore, MC have been identified as early targets of inflammatory processes in a variety of glomerular diseases [33].

Since the role of the different EP receptors in inflammatory renal diseases is unclear, the current study investigates a possible role of EP2 receptor deficiency in LPS-induced nephritis and focuses on the role of EP receptors on CCL2 expression in a simplified experimental model. For this purpose we chose an in vitro model using stimulated MC with constitutively enhanced PGE2 secretion and down regulated EP receptor expression (COX$2+$ cells). By selective overexpression of EP receptors in these cells, their effects on LPSinduced CCL2 expression are examined. 


\section{MATERIALS AND METHODS}

\section{LPS-induced nephritis}

LPS-induced nephritis was induced by intraperitoneal LPS (E coli O111:B4) injection in wild-type C57BL/6 (Charles River, Germany) and EP2 receptor knock out mice (EP2ko), lacking the EP2 receptor [34] as described earlier [26]. The animals were bred in house under flow sterile conditions. The experiments were performed with $3 \mathrm{mg} / \mathrm{kg}$ body weight LPS. Kidneys were examined at 3 and 24 hours after LPS-injection.

All animal experiments were performed according to national and institutional animal care and ethical guidelines and have been approved by the local ethical committee.

\section{Cell lines and transient transfections}

Mouse wildtype as well as EP2 prostaglandin receptor knockout MC (EP2ko MC) were established from glomeruli of appropriate animals by differential sieving and characterized as described earlier [35]. Vector control (VC) and COX-2+ cells were used as previously described [36]. The cell lines were maintained in RPMI-1640 containing $10 \%$ FCS. COX-2+ and VC cells additionally received $200 \mu \mathrm{g} / \mathrm{ml}$ zeocin or $200 \mu \mathrm{g} / \mathrm{ml} \mathrm{G418}$ respectively (both Invitrogen) at $37^{\circ} \mathrm{C}$ in $5 \% \mathrm{CO}_{2}$.

For transient transfection, $2 \times 10^{5} \mathrm{WT}$ or COX-2+ cells were seeded in six well plates and cultivated over night. For RNA experiments $2 \mu \mathrm{g}$ of the appropriate EP expression construct (EP1- 4 full length cloned in pcDNA3.1neo; Missouri S\&T Resource Center) or 2 $\mu \mathrm{g}$ of the empty pcDNA 3.1neo vector and $0.5 \mu \mathrm{g}$ of a $ß$-galactosidase expression construct (Stratagene) were co-transfected four hours by using the Plus ${ }^{\mathrm{TM}} /$ Lipofectamine $^{\mathrm{TM}}$ LTX system (Invitrogen) according to the manufacturor's recommendations. To recover cells and ensure expession of the transfected DNA-constructs, transfection media was removed and cells were cultivated over night in RPMI-1640 containing $0.5 \%$ FCS. Then, LPS stimulation was performed in serum free RPMI-1640 media.

\section{Microdissection of glomeruli}

For microdissection of glomeruli, $12 \mu \mathrm{m}$ thick cryosections were generated and stained by cresylviolett. Approximately 150 glomeruli sections were cut directly out of the tissue by using a Palm Microm Beam microscope (Palm Microlaser Technologies, Germany) and captured in tissue lysis buffer.

\section{RNA isolation, cDNA synthesis and quantitative real time PCR analysis}

Total RNA isolation of MC was performed by the Nucleo Spin RNA-II Kit (Macherey \& Nagel), and total RNA isolation of microdissected glomeruli using the Micro RNA Preparation Kit (Quiagen, Germany), both according to the manufacturer's recommendations.

Total RNA of 150 microdissected glomeruli or MC (200 ng) was reverse transcribed with $100 \mathrm{U}$ M-MLV reverse transcriptase (Invitrogen) for 50 minutes at $37^{\circ} \mathrm{C}$ and enzyme activity was subsequently stopped by incubation for 15 minutes at $70{ }^{\circ} \mathrm{C}$. cDNA corresponding to 150 glomeruli or $10 \mathrm{ng}$ total cellular RNA respectively was subjected to SYBR Green based real time PCR quantification using the SYBR Green JumpStart kit 
(Sigma). To assess differences in cDNA quality the probes were normalized to 18S rRNA expression. The following primers were used:

\author{
CCL2: FW: 5’CTCAGCCAGATGCAGTTAATG 3' \\ Rev: 5'TTCTCCAGCCGACTCATTGG 3' \\ 18S: FW: 5'CACGGCCGGTACAGTGAAAC3' \\ Rev: 5'AGAGGAGCGAGCGACCAAA 3'
}

\title{
PGE2 binding assay
}

Same amounts of quiescent VC and COX-2+ cells were treated with various amounts (6-48 nmol) of [3H]-labeled PGE2 (Amersham) in the presence of $500 \mathrm{nmol}$ cold PGE2 (Cayman Chemical) for 30 minutes. Thereafter, cells were washed four times in PBS and then trypsinized. The $[3 \mathrm{H}]$-content of the cell solution was subsequently measured in a $\mathrm{B}$ szintilation counter (Packard).

\section{CCL2 ELISA}

Conditioned media of cells were collected and quantitated by the CCL2 Instant ELISA (Bender Medsystems) according to the manufacturer's recommendations. CCL2 was normalized to total cellular protein of the appropriate sample.

\section{Western blot analysis}

Western blot analysis was performed as published earlier [36]. All anti human EP primary antibodies were obtained from Cayman Chemical and the anti human ß-actin was purchased from Sigma. They were all used at a dilution of 1:1.000. For detection, an antirabbit-IgG antibody (all EP receptors) or an anti-mouse-IgG (ß-actin) conjugated to alkaline phosphatase (Southern Biotechnology) at a concentration of 1:5.000 were used.

\section{Statistical analysis}

The data are presentated as the means \pm S.D. Statisitical significance between different groups was first tested with the non-parametric Kruskal-Wallis test. Individual groups were subsequently tested using the Wilcoxon-Mann-Whitney test. A P value $<0.05$ was considered significant. 


\section{RESULTS}

\section{EP2 receptor deficiency modulates CCL2 expression in LPS-induced nephritis}

To examine whether EP2 receptor deficiency influences the expression of the proinflammatory chemokine CCL2 in LPS-induced nephritis, nephritic wild-type (wt) and EP2ko animals were sacrified 3 and 24 hours after LPS injection. Total RNA was isolated from renal cortex and micro-dissected glomeruli and quantitative CCL2 RNA expression analysis was performed.

LPS strongly induced CCL2 RNA expression in kidney cortex of wt and EP2ko mice, but there was no difference between wt and EP2ko mice at both time points studied when examining crude cortex preparations (data not shown). Examination of RNA from microdissected glomeruli (figure 1A), however, showed that glomerular CCL2 expression was upregulated three hours after LPS injection in EP2ko mice (2.53 fold \pm 1.14 ). 24 hours post LPS injection CCL2 RNA expression levels were similar in both wt and EP2ko-mice.

\section{LPS-induced CCL2 expression is modified by different EP receptors in mesangial cells}

To confirm a participation of prostaglandin E receptors in LPS stimulated CCL2 expression on a cellular level, quiescent wild type mouse MC (WT) and EP2 knockout mouse MC (EP2ko) were stimulated with $1 \mu \mathrm{g} / \mathrm{ml}$ LPS for three hours in the presence $(10 \mu \mathrm{M})$ or absence of an EP4 antagonist GW 627368X (GW) after pre-treatment for one hour with GW.

Figure 1B shows that LPS stimulates CCL2 RNA expression in WT cells (127.65 \pm 17.32 fold). In EP2ko cells lacking the EP2 receptor, the LPS-induced stimulation of CCL2 RNA expression is enhanced (299.54 \pm 150.96 fold). This LPS-induced stimulation of CCL2 is comparable in the presence of $10 \mu \mathrm{M}$ EP4 antagonist in WT (310.6 $\pm 55.3 \mathrm{fold}$ ), and even more pronounced in EP2ko cells (786.25 \pm 311.3 fold). Treatment of both cell lines with the EP4 antagonist in the absence of LPS did not show any significant effect (data not shown).

In figure 1C, CCL2 protein secretion into cell culture supernatant for six hours in the same experimental setting is demonstrated. LPS-induced WT cells secrete $31.8 \pm 5.2 \mathrm{pg}$ while EP2ko cells secrete $199.7 \pm 28.3 \mathrm{pg} / \mathrm{mg}$ total cellular protein. In the presence of the EP4 antagonist CCL2 protein secretion is further enhanced in WT $(217.2 \pm 26.5 \mathrm{pg} / \mathrm{mg})$ as well as in EP2ko cells (290.7 $\pm 40.1 \mathrm{pg} / \mathrm{mg})$.

\section{Transient overexpression of EP2 and EP4 receptors influence LPS-induced CCL2 expression in WT cells}

The data depicted in figure 1A-C imply a potential role of EP2 and EP4 receptors on LPS-induced CCL2 gene expression. To further examine this hypothesis, overexpression of EP2 and EP4 receptors in WT cells were performed. WT cells were transiently transfected with either EP2 or EP4 receptor DNA or mock transfected. One day later the cells were LPS stimulated for three hours or pre-incubated for one hour with $1 \mu \mathrm{M}$ PGE2 and then LPS stimulated for another three hours in the presence of PGE2.

As shown in figure $1 \mathrm{D}$, overexpression of EP2 (0.74 \pm 0.1 fold) or EP4 receptors (0.83 \pm 0.1 fold) in WT cells slightly reduced LPS-induced CCL2 RNA expression. In the presence of $1 \mu \mathrm{M}$ PGE2 the LPS-induced reduction of CCL2 RNA is further reduced (EP2: $0.54 \pm 0.14$ fold; EP4: $0.5 \pm 0.17$ fold). 


\section{Cells with stimulated PGE2 secretion show a reduced EP receptor cell surface expression due to Prostaglandin E receptor downregulation}

The results of the transient overexpression of EP2 and EP4 receptors in WT cells (figure 1D) indicate a possible role of PGE2 stimulated EP receptors in the regulation of CCL2 gene expression. To examine this effects in more detail, we chose to use a cell line with constitutively stimulated PGE2 secretion (COX-2+) [36]. This is to overcome some problems using wild type cells with unstable exogenous delivery of PGE2 due to lability of dissolved PGE2 stocks, and also a possible ongoing regulation of EP receptors under this setting. We expect that the permanent availability of freshly generated, bioactive PGE2 in COX-2+ cells is an important assumption to examine overexpression of different EP receptor pathways which may enable understanding of an individual EP receptor function.

To detect a possible EP receptor downregulation in the presence of enhanced PGE2, [3H]-labeled PGE2 binding was examined in COX-2+ cells and vectorcontrol cells (VC). These cells were pulsed for 30 minutes with the indicated amounts of [3H]-labeled PGE2 (6 $-48 \mathrm{nmol}$ ) in serum free culture media. Total PGE2 binding was significantly reduced in COX-2+ cells visible at $24 \mathrm{nmol}$ [3H]-labeled PGE2 (figure 2A) suggesting a PGE2 dependent significantly reduced EP-receptor cell surface expression.

In order to confirm the binding results on EP receptor levels appropriate RNA expression and immunoblot analysis were performed. As demonstrated in figures $2 \mathrm{~B}$ and $\mathrm{C}$, the expression of EP1, EP2, EP3 and EP4 receptors were significantly downregulated in COX-2+ cells on RNA as well as on protein levels. Unfortunately, the available antibody against the EP3 receptor from Cayman did not detect any isoform in our MC.

In accordance to the data of enhanced CCL2 protein secretion in EP 2/4 knock-down as shown in figure 1 , CCL2 protein secretion of LPS treated COX-2+ cells (674.6 \pm 184.8 $\mathrm{pg} / \mathrm{mg}$ ) is significantly increased compared to VC cells (68.8 $\pm 14.8 \mathrm{pg} / \mathrm{mg}$ ) (figure 2D).

\section{Overexpression of EP receptors and CCL2 expression}

In order to examine the exact role of a single EP receptor, overexpression experiments in the COX-2+ cell line with constitutively activated PGE2 secretion and consequently downregulated EP receptor cell surface expression were performed.

Either EP1, EP2, EP3 or EP4 were transiently overexpressed in COX-2+ cells and expression of the different EP receptors was examined $24 \mathrm{~h}$ post transfection at first. As shown in figure 3, RNA as well as protein expression of the EP1, EP2, EP3 and EP4 receptor are enhanced. Unfortunately, protein expression of the EP3 receptor could not be detected with the available antibody.

Then, 24 hours post transfection COX-2+ cells were further treated with $1 \mu \mathrm{g} / \mathrm{ml} \mathrm{LPS}$ for three hours and compared to LPS-induced mock transfected COX-2+ cell line. As depicted in figure 4 , overexpression of EP1 (RNA: $1.22 \pm 0.43$ fold; protein: $647.6 \pm 110.6$ $\mathrm{pg} / \mathrm{mg}$ ) as well as EP3 (RNA:1.42 \pm 0.53 fold; protein: $669.4 \pm 170.2 \mathrm{pg} / \mathrm{mg}$ ) hardly influenced LPS-induced CCL2 expression. In contrast, overexpression of EP2 (RNA: $0.22 \pm$ 0.05 fold; protein: $185.7 \pm 23.9 \mathrm{pg} / \mathrm{mg}$ ) as well as EP4 receptors (RNA: $0.35 \pm 0.07$ fold; protein: $197.2 \pm 28.5 \mathrm{pg} / \mathrm{mg}$ ) significantly decreased LPS induced CCL2 expression. 


\section{DISCUSSION}

A characteristic feature of many diseases associated with inflammatory processes and also different forms of glomerulonephritis is the early upregulation of COX-2 dependent PGE2 formation [6 - 9]. This upregulation can be mediated, at least partly and experimentally, by the action of pro-inflammatory inducers such as IL-1ß [4] or LPS [5]. However, prostaglandins of the E series produced during the inflammatory process can also downregulate expression of pro-inflammatory chemokines, as has been demonstrated for CCL2 in experimental glomerulonephritis [27, 28]. A complex pattern of pro- [22] as well as anti-inflammatory [23] effects may therefore be obtained in response to PGE2. PGE2 may differently influence inflammatory processes depending on the kind of model or disease, but also on the timepoint of its expression during the course of the inflammation and the distribution on the surfaces of the different cells implicated.

mRNA of the EP1 and EP4 receptor and a possible regulation was first reported under high glucose conditions on rat mesangial cells in culture by Ishibashi et al. [37]. Other authors described EP2 receptor mRNA in rat mesangial cells in culture [38, 39], conflicting results were published on the presence of EP3 receptor mRNA in mesangial cells. To date the reports do not give a clear picture on EP receptor distribution or possible regulation on mesangial cells. A possible role of EP receptors in experimental or human nephritis is even more unclear. Experiments with a model of nephrotoxic nephritis suggest an enhanced susceptibility of renal dysfunction in mice lacking the EP1 receptor [40]. Evidence for a protective role of the EP4 receptor in nephritis comes from studies using an EP4 receptor agonist in an anti-GBM model of nephritis in mice [41], and studies using an EP4 receptor antagonist in a PAN model of nephritis in rats [39].

We were interested whether mice deficient in EP2 receptor expression show a different inflammatory response compared to wild type mice. We chose the LPS-induced nephritis model for our examinations, because LPS is a rapid inducer of the inflammatory process with a strong stimulation of CCL2. The pro-inflammatory chemokine CCL-2 is known to be expressed in the early phases of different forms of immune mediated glomerulonephritis [24 - 26] and its expression may be modulated through PGE2 [27, 28]. Our experiments demonstrate that glomerular CCL2 expression is enhanced in the early phase of LPS-induced nephritis in EP2 deficient mice compared to wt mice. This further suggests a potential role of PGE2 and EP receptors in CCL2 regulation in this model. More specifically, the observed effect of EP2 deficiency is restricted to glomeruli, implicating a potential role of mesangial cells.

Earlier experiments with mesangial cells have pointed toward an effect of Prostaglandin mediated CAMP stimulation in the regulation of inflammation [42]. Thus, in addition to the EP2 receptor, the EP4 receptor is another candidate in mediating similar effects. Unfortunately, standard constitutive EP4 knock-out mice die pre-natally [43 - 45] and conditional EP4 knock-out mesangial cells have not been generated.

To gain more insight into the role of prostaglandin E receptors in PGE2 mediated inflammatory processes, we further examined LPS-induced CCL2 gene expression in cultured MC with specific EP receptor expression.

Initial cell culture experiments were performed in wildtype MC (WT) and MC lacking the EP2 receptor (EP2ko). In EP2ko cells CCL2 gene expression is enhanced in response to LPS. Corresponding results could be obtained in LPS-induced WT cells in the presence of a specific EP4 receptor antagonist. In addition, blocking EP4 receptor in EP2ko cells further enhanced LPS-induced CCL2 gene expression. Thus, the availability of active EP2 and EP4 receptors seem to be necessary to confine the strong inflammatory effects of LPS. In order to proof this hypothesis, we performed transient overexpression of each EP receptor and 
measured CCL2 gene expression a master player in early inflammatory processes in a variety of immune mediated glomerulonephritis [7 - 9].

Since prostaglandins, including PGE2, are very sensitive fatty acids but significant amounts of bioactive extracellular PGE2 should be necessary to induce reconstituted EP receptors, we decided to test a MC line that permanently generates bioactive PGE2 due to constitutive overexpression of COX-2 (COX-2+ cells) [36]. PGE2 binding assays demonstrated a significantly reduced cell surface binding of PGE2 in these COX-2+ cells, and the expected downregulation of EP receptors due to the high extracellular PGE2 content. Stimulation with LPS strongly induced CCL2 gene expression and NF- $\kappa \mathrm{B}$ activity in these cells. Thus, they seem to be a good in vitro model with low basal EP receptor cell surface expression (low background) and high amounts of bioactive PGE2 (no further stimulation with labile exogenous PGE2 necessary) to study the effects of individual EP receptors on CCL2 through transient overexpression of each receptor. Overexpression of the Gs coupled EP2 as well as EP4 receptors, signaling through activation of the second messenger cAMP, result in a significant reduction of LPS-induced mRNA expression of the pro-inflammatory chemokine CCL2. These observations confirm the initial EP2 receptor knockdown and EP4 receptor blocking experiments. In contrast, neither EP3 nor EP1 receptor overexpression is sufficient to affect CCL2 RNA expression. The EP2 receptor dependent reduction of CCL2 RNA expression is more potent than the appropriate reduction dependent on EP4 receptor overexpression. Differences between the EP2 receptor triggered activation of cAMP dependent signal transduction pathways [18, 19], mainly activation of protein kinase A [46] and the EP4 possible receptor dependent activation of PI3 kinase accompanied with a subsequent activation of the erk 1/2 MAP-kinase [21] may explain these differences. Examinations of the different relevant signaling pathways will clarify these discrepancies.

In conclusion, in vivo observations in LPS-induced nephritis suggest an implication of PGE2 and its specific E2 receptor in the acute phase of inflammation. By using an in vitro model with down regulated EP receptors and therefore strongly reduced background noise, the EP2 and EP4 receptors but not the EP1 and EP3 receptors, were identified as important modulators of PGE2 mediated inflammatory effects as measured by CCL-2 expression. The downregulation of EP2 as well as EP4 receptors result in an imbalance of the inflammatory state of mesangial cells. Data presented in the current study identify the EP2 and EP4 receptors as potential feedback mediators of inflammatory PGE2 effects in these cells. EP2 and EP4 receptors may be important to mediate COX-2 metabolite-dependent downregulation of pro-inflammatory chemokine expression such as CCL2 in glomerulonephritis.

\section{DISCLOSURE}

None 


\section{REFERENCES}

1. Needleman P., Turk J., Jaschik B., Morrison A., Lefkowith J. (1998) Arachidonic acid metabolism. Annu. Rev. Biochem. 55, 69-102

2. Murakami M., Naraba H., Tanioka T., Semmyo N., Nakatani Y., Kojima F., Ikeda T., Fueki M., Ueno A., Ohishi S., Kudo I. (2000) Regulation of prostaglandin E2 biosynthesis by inducible membrane-associated prostaglandin E2 synthase that acts in concert with cycclooxygenase-2. J. Biol. Chem. 275, 32783-32792

3. Schneider A., Zhang Y., Zhang M., Lu W.J., Fan X., Redha R., Davis L., Breyer R.M., Harris R., Guan Y.F, Breyer M.D. (2004) Membrane-associated PGE synthase-1 (mPGES-1) is coexpressed with both COX-1 and COX-2 in the kidney. Kidney Int. 65, 1205-1213

4. Rzymkiewicz D., Leingang K., Baird N., Morrison A.R. (1994) Regulation of prostaglandin endoperoxide synthase gene expression in rat mesangial cells by interleukin-1 beta. Am. J. Physiol. 266, F39-F45

5. Hwang D., Jang B.C., Yu G., Boudreau M. (1997) Expression of mitogen-inducible cyclooxygenase induced by lipopolysaccharide: mediation through both mitogenactivated protein kinase and NF-kappaB signaling pathways in macrophages. Biochem. Pharmacol. 54, 87-96

6. Crofford L.J., Wilder R.L., Ristimäki A.P., Sano H., Remmers E.F., Epps H.R., Hla T. (1994) Cyclooxygenase-1 and -2 expression in rheumatoid synovial tissues: Effects of interleukin-1 beta, phorbol ester, and corticosteroids. J. Clin. Invest. 93, 1095-1101

7. Hirose S., Yamamoto T., Feng L., Yaoita E., Kawasaki K., Goto S., Fujinaka H., Wilson C.B., Arakawa M., Kihara I. (1998) Expression and localization of cyclooxygenase isoforms and cytosolic phospholipase A2 in anti-Thy-1 glomerulonephritis. J. Am. Soc. Nephrol. 9, 408-416

8. Blume C., Heise G., Mühlfeld A., Bach D., Schrör K., Gerhardz C.D., Grabensee B. Heering P. (1999) Effect of flosulide, a selective cyclooxygenase 2 inhibitor, on passive heymann nephritis in the rat. Kidney Int. 56, 1770-1778

9. Tomasoni S., Noris M., Zappella S., Gotti E., Casiraghi F., Bonazzola S., Benigni A., Remuzzi G. (1998) Upregulation of renal and systemic cyclooxygenase-2 in patients with active lupus nephritis. J. Am. Soc. Nephrol . 9, 1202-1212

10. Cattell V., Smith J., Cook H.T. (1990) Prostaglandin E1 suppresses macrophage infiltration and ameliorates injury in an experimental model of macrophage-dependent glomerulonephritis. Clin. Exp. Immunol. 79, 260-265

11. Kelley V.E., Winkelstein A., Izui S. (1979) Effect of prostaglandin E on immune complex nephritis in NZB/W mice. Lab. Invest. 41, 531-537

12. Schneider A., Thaiss F., Rau H.P., Wolf G., Zahner G., Jocks T., Helmchen U., Stahl R.A.K. (1996) Prostaglandin E1 inhibits collagen expression in ani-thymocyte antibodyinduced glomeruonephritis: Possible role of TGFß. Kidney Int. 50, 190-199

13. Funk C.D., Furci L., FitzGerald G.A., Grygorczyk R., Rochettem C., Bayne M.A., Abramovitz M., Adam M., Metters K.M. (1993) Cloning and expression of a cDNA for the human prostaglandin E receptor EP1 subtype. J. Biol. Chem. 268, 26868-26772

14. Watabe A., Sugimoto Y., Honda A., Irie A., Namba T., Negishi M., Ito S., Narumiya S., Ichikawa A. (1993) Cloning and expression of cDNA for a mouse EP1 subtype of prostaglandin E receptor. J. Biol. Chem. 268, 20175-20178

15. Sugimoto Y., Namba T., Honda A., Hayashi Y., Negishi M., Ichikawa A., Narumiya S. (1992) Cloning and expression of a cDNA for mouse prostaglandin receptor EP3 subtype. J. Biol. Chem. 267, 6463-6466

16. Irie A., Sugimoto Y., Namba T., Harazono A., Honda A., Watabe A., Negishi M., Narumiya S., Ichikawa A. (1993) Third isoform of the prostaglandin-E-receptor EP3 
subtype with different C-terminal tail coupling to both stimulation and inhibition of adenylate cyclase. Eur. J. Biochem. 217, 313-318

17. Nambe T., Sugimoto Y., Negishi M., Irie A., Ushikubi F., Kakizuk A., Ito S., Ichikawa A., Narumiya S. (1993) Alternative splicing of C-terminal tail of of prostaglandin E receptor subtype EP3 determines G-protein specifity. Nature 365, 166-170

18. Honda A., Sugimoto Y., Namba T., Watabe A., Irie A., Negishi M., Narumiya S., Ichikawa A. (1993) Cloning and expression of a cDNA for mouse prostaglandin E receptor EP2 subtype. J. Biol. Chem. 268, 7759-7762

19. Regan J.W., Bailey T.J., Pepperl D.J., Pierce K.L., Bogardus A.M., Donello J.E., Fairbairn C.E., Kedzie K.M., Wodward D.F., Gil D.W. (1994) Cloning of a novel human prostaglandin receptor with characteristics of the pharmacologically defined EP2 subtype. Mol. Parmacol. 46, 213-220

20. Fujino H., West K.A., Regan J.W. (2002) Phosphorylation of glycogen synthase kinase-3 and stimulation of T- cell factor signaling following activation of EP2 and EP4 prostanoid receptors by prostaglandin E2. J. Biol. Chem. 277, 2614-2619

21. Fujino H., Xu W., Regan J.W. (2003) Prostaglandin E2 induced functional expression of early growth response factor-1 by EP4, but not EP2, prostanoid receptors via the phosphatidylinositol 3-kinase and extracellular signal-regulated kinases. J. Biol. Chem. 278, 12151-12156

22. Montine T.J., Milatovic D., Gupta R.C., Valyi-Nagy T., Morrow J.D., Breyer R.M. (2002) Neuronal oxidative damage from activated innate immunity is EP2 receptordependent. J. Neurochem. 83, 463-470

23. Takayama K., Garcia-Cardena G., Sukhova G.K., Comander J., Gimbrone Jr. M.A., Libby P. (2002) Prostaglandin E2 suppresses chemokine production in human macrophages through the EP4 receptor. J. Biol. Chem. 277, 44147-44154

24. Stahl R.A.K., Thaiss F., Disser M., Helmchen U., Hora K., Schlöndorff D. (1993) Increased expression of monocyte chemoattractant protein-1 in anti-thymocyte antibodyinduced glomerulonephritis. Kidney Int. 44, 1036-1047

25. Rovin B.H., Rumancik M., Tan L., Dickerson J. (1994) Glomerular expression of monocyte chemoattractant protein-1 in experimental and human glomerulonephritis. Lab. Invest. 71, 536-542

26. Haberstroh U., Pocock J., Gómez-Guerrero C., Helmchen U., Hamann A., GutierrezRamos J.C., Stahl R.A.K., Thaiss F. (2002) Expression of the chemokine MCP-1/CCL2 and RANTES/CCL5 is differentially regulated by infiltrating inflammatory cells. Kidney Int. 62, 1264-1276

27. Schneider A., Harendza S., Zahner G., Jocks T., Wenzel U., Wolf G., Thaiss F., Helmchen U., Stahl R.A.K. (1999) Cyclooxygenase metabolites mediate glomerular monocyte chemoattractant protein-1 formation and monocyte recruitment in experimental glomerulonephritis. Kidney Int. 55, 430-441

28. Jocks T., Zahner G., Freudenberg J., Wolf G., Thaiss F., Helmchen U., Stahl R.A.K. (1996) Prostaglandin E1 reduces the glomerular mRNA expression of monocytechemoattractant protein 1 in anti-thymocyte antibody-induced glomerular injury. J. Am. Soc. Nephrol. 7, 897-905

29. Mené P., Simonson M.S., Dunn M.J. (1989) Physiology of the mesangial cell. Physiol. Rev. 69, 1347-1424

30. Rovin B.H., Yoshimura T., Tan L. (1992) Cytokine-induced production of monocyte chemoattractant protein-1 by cultured human mesangial cells. J. Immunol. 148, 21482153

31. Satriano J.A., Hora K., Shan Z., Stanley E.R., Mori T., Schlöndorff D. (1993) Regulation of monocyte chemoattractant protein-1 and macrophage colony-stimulating factor-1 by 
IFN-gamma, tumor necrosis factor-alpha, IgG aggregates, and cAMP in mouse mesangial cells. J. Immunol. 150, 1971-1978

32. Grandaliano G., Valente A.J., Rozek M.M., Abboud H.E. (1994) Gamma interferon stimulates monocyte chemotactic protein (MCP-1) in human mesangial cells. J. Lab. Clin. Med. 123, 282-289

33. Schneider A., Panzer U., Zahner G., Wenzel U., Wolf G., Thaiss F., Helmchen U., Stahl R.A.K. (1999) Monocyte chemoattractant protein-1 mediates collagen deposition in experimental glomerulonephritis by transforming growth factor-beta. Kidney Int. 56, 135144

34. Breyer R.M., Kennedy C.R., Zhang Y., Guan Y., Breyer M.D. (2002) Targeted gene disruption of the prostaglandin EP2 receptor. Adv. Exp. Med. Biol. 507, 321-326

35. Wolf G., Haberstroh U., Neilson E.G. (1992) Angiotensin II stimualtes the proliferation and biosynthesis of type I collagen in cultured murine mesangial cells. Am. J. Path. 140, 95-107

36. Zahner G., Wolf G., Ayoub M., Reinking R., Panzer U., Shankland S.J., Stahl R.A.K. (2002) Cyclooxygenase-2 overexpression inhibits platelet-derived growth factor-induced mesangial cell proliferation through induction of the tumor suppressor gene p53 and the cyclin-dependent kinase inhibitors p21 ${ }^{\text {waf-1/cip-1 }}$ and p27 $7^{\text {kip-1 }}$. J. Biol. Chem. 277, 97639771

37. Ishibashi R., Tanaka I., Kotani M., Muro S., Goto M., Sugawara A., Mukoyama M., Sugimoto Y., Ichikawa A., Narumiya S., Nakao K. (1999) Roles of prostaglandin E receptors in mesangial cells under high-glucose conditions. Kidney Int. 56, 589-490

38. Hartner A., Pahl A., Brune K., Goppelt-Strube M. (2000) Upregulation of Cox-1 and the PGE2 receptor EP2 in rat and human mesangioproliferative glomerulonephritis. Inflamm. Res. 49, 345-354

39. Aoudjit L., Potapov A., Takano T. (2006) Prostaglandin E2 promotes cell survival of glomerular epithelial cells via the EP4 receptor. Am. J. Physiol. 290, F1534-F1542

40. Rahal S., McVeigh L.I., Zhang Y., Guan Y., Breyer M.D., Kennedy C.R. (2006) Increased severity of renal impairment in nephritis mice lacking the EP1 receptor. Can. J. Physiol. Pharmacol. 84, 877-885

41. Nagamatsu T., Imai H., Yokoi M., Nishiyama T., Hirasawa Y., Nagao T., Suzuki Y. (2006) Protective effect of prostaglandin EP4-receptor agonist on anti-glomerular basement membrane antibody-associated nephritis. J. Pharmacol. Sci. 2, 182-188

42. Zahner G., Disser M., Thaiss F., Wolf G., Schoeppe W., Stahl R.A. (1994) The effect of prostaglandin E2 on mRNA expression and secretion of collagens I, III, and IV and fibronectin in cultured rat mesangial cells. J. Am. Soc. Nephrol. 4, 1778-1885

43. Segi E., Sugimoto Y., Yamasaki A., Aze Y., Oida H., Nishimura T., Murata T., Matsuoka T., Ushikubi F., Hirose M., Tanaka T., Yoshida N., Narumiya S., Ichikawa A. (1998) Patent ductus arteriosus and neonatal death in prostaglandin receptor EP4-deficient mice. Biochem. Biophys. Res. Commun. 246, 7-12

44. Nguyen M., Camenisch T., Snouwaert J., Hicks E., Coffman T., Anderson P., Malouf N., Koller B. (1997) The prostaglandin receptor EP4 triggers remodelling of the cardiovascular system at birth. Nature 390, 78-81

45. Schneider A., Guan Y., Zhang A., Magnuson M.A., Pettepher C., Loftin C.D., Langenbach R., Breyer R.M., Breyer M.D. (2004) Generation of a conditional allele of the mouse prostaglandin EP4 receptor. Genesis 40, 7-14

46. Regan J.W. (2003) EP2 and EP4 prostanoid receptor signaling. Life. Sci. 74, 143-153 


\section{FIGURE LEGENDS}

\section{Figure 1:}

A: In LPS-induced nephritis glomerular CCL2 expression is upregulated three hours after LPS injection in EP2ko mice (2.53 fold \pm 1.14). 24 hours post LPS injection CCL2 RNA expression levels are similar in wild-type and EP2ko mice. Data are expressed as x-fold LPS induction of EP2ko versus the appropriately treated wild-type mice.

B: Blockade of the EP4-receptor by $10 \mu \mathrm{M}$ GW 627368X significantly stimulates LPS-induced CCL2 RNA expression in WT cells ( $\mathrm{n}=3$, ${ }^{*} \mathrm{p}<0.01$ vs. LPS-induced WT cells). In EP2ko cells, LPS-induced CCL2 RNA expression is enhanced and in the presence of GW 627368X, LPS significantly induced CCL2 RNA expression ( $\mathrm{n}=3$, \#p $<0.05$ vs. LPS-induced EP2ko cells). Data are expressed as x-fold LPS-induced vs. the appropriate serum free control.

C: LPS-induced CCL2 protein secretion in WT and EPko cells with or without GW $627368 \mathrm{X}$ is depicted. LPS significantly stimulates CCL2 protein secretion in EP2ko and in GW-treated WT cells ( $n=3,{ }^{*} p<0.01$ vs. LPS-induced WT cells). In GW-treated EP2ko cells CCL2 protein secretion is further enhanced ( $n=3$, \# $p<0.01$ vs. LPS-induced WT cells). Results were normalized in respect to the corresponding cell line incubated under serum free conditions. Incubation of the cell lines with GW alone showed no significant effects (data not shown).

D: CCL2 RNA expression of WT cells mock or transiently transfected either with EP2 or EP4 receptor is shown. LPS-induced CCL2 expression is slightly reduced in EP receptor over-expressing WT cells. Addition of PGE2 $(1 \mu \mathrm{M})$ further reduced CCL2 expression. All treatments were compared to LPS-induced and mock transfected WT cells.

\section{Figure 2:}

\section{Characterization of the in vitro model:}

A: Cell surface binding of [3H]-labeled PGE2 on VC and COX-2+ cells under serum free conditions. Beginning at $24 \mathrm{nmol}$, [3H]-labeled PGE2 COX-2+ cells significantly showed less binding than VC cells $\left(\mathrm{n}=3\right.$, ${ }^{*} \mathrm{p}<0.05$; $\left.\# \mathrm{p}<0.01\right)$.

B: EP receptor RNA expression of COX-2+ cells are significantly reduced. Data are expressed as $\mathrm{x}$-fold vs VC $\left(\mathrm{n}=4,{ }^{*} \mathrm{p}<0.01\right)$.

C: Representative EP1, EP2, and EP4 receptor immuno blot analysis of WT and COX-2+ cells (one of three experiments). COX-2+ cells showed reduced EP protein expression when compared to VC cells.

D: CCL2 protein secretion (6 h) of LPS-induced COX-2+ cells is significantly increased ( $\mathrm{n}=4,{ }^{*} \mathrm{p}<0.01$ vs. VC). Data are expressed as $\mathrm{pg} / \mathrm{mg}$ of total cellular protein. 


\section{Figure 3:}

To confirm enhanced EP receptor expression 24 hours post transfection RNA expression (A) and a representative immuno blot analysis (B) are depicted (one of three independent experiments). As expected, overexpression of a single receptor enhanced appropriate receptor RNA and protein expression but did not influence expression of the other EP receptors. Since we could not detect EP3 protein with the available antibody (Cayman), an EP3 immuno blot is not shown.

\section{Figure 4:}

LPS-induced CCL2 expression of COX-2+ cells either mock or transfected separately with an appropriate EP expression construct is shown. Transient transfection of either EP2 or EP4 receptors significantly decreased LPS-induced CCL2 RNA expression (A) or protein secretion (B) ( $=3, * \mathrm{p}<0.01$ vs. mock transfected), while transfection of EP1 or EP3 did not. CCL2 RNA expression is normalized against LPS-induced mock transfected COX-2+ cells. LPS-induced CCL2 protein secretion is expressed as pg CCL2/mg total cellular protein. 


\section{Figure 1:}

A:

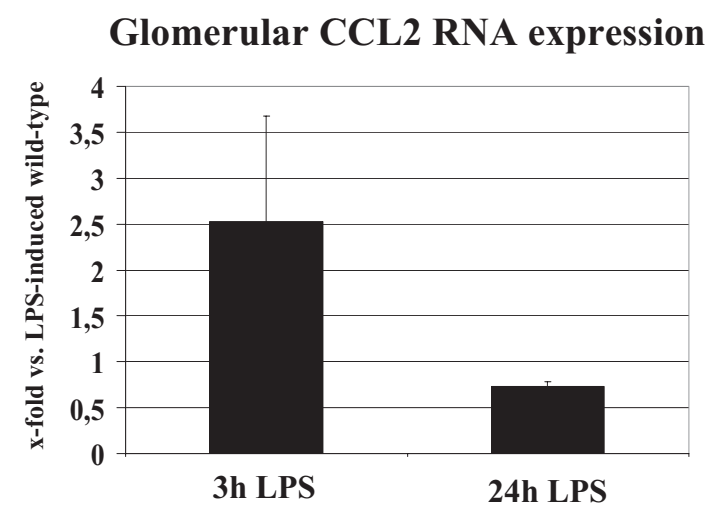

C:

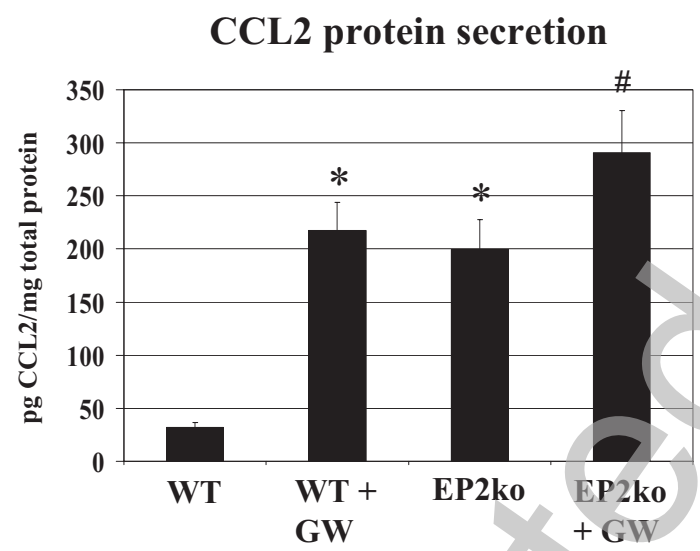

B:

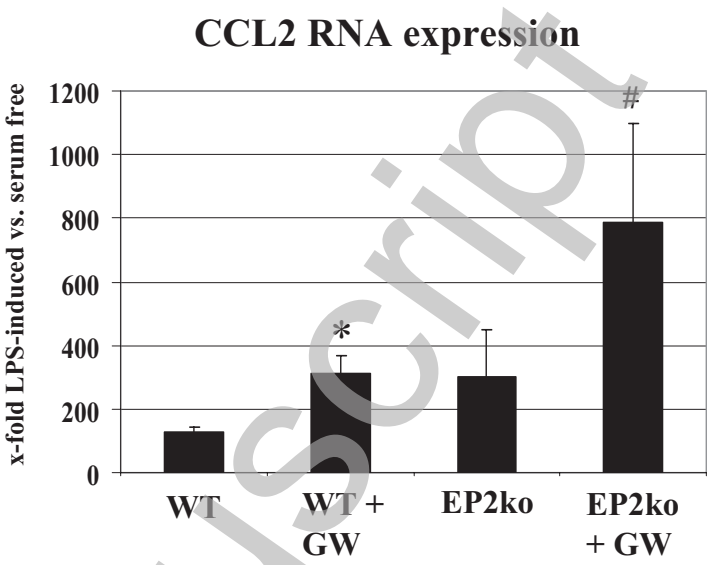

D:

\section{CCL2 RNA expression}

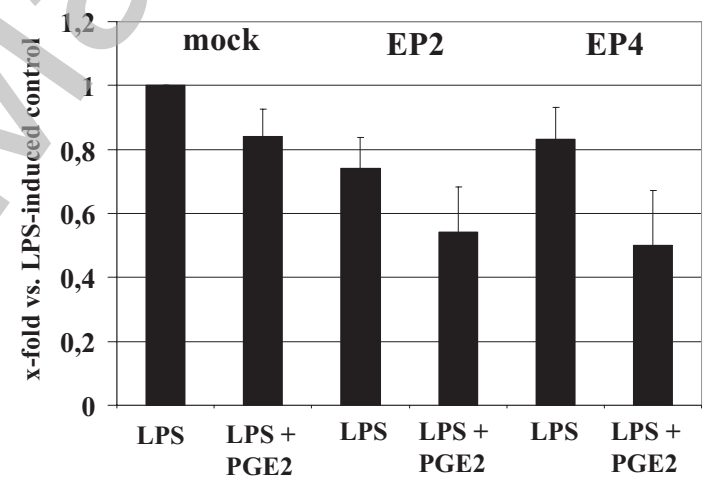




\section{Figure 2:}

A:

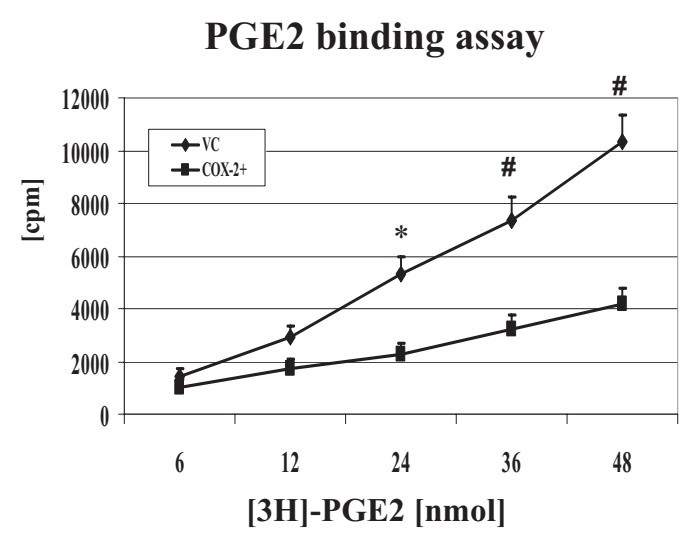

C:

\section{EP receptors protein expression}

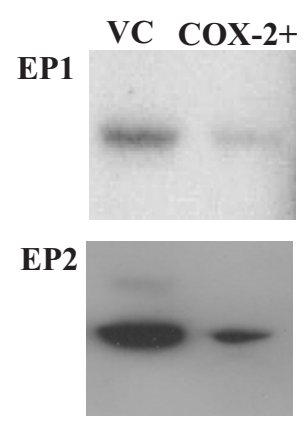

EP4

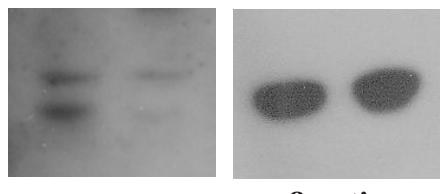

B-actin
B:

\section{EP receptor RNA expression}

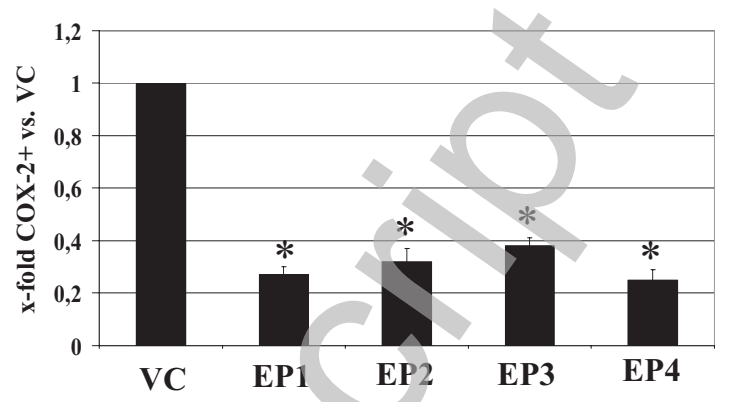

D:

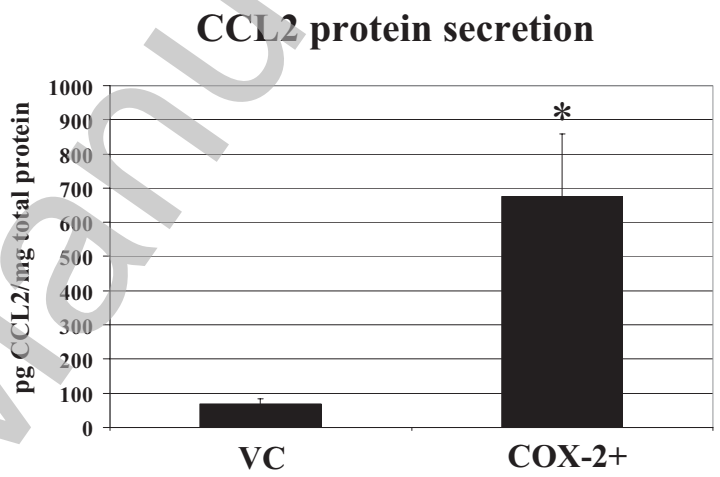




\section{Figure 3:}

A:

EP receptor RNA over-expression in COX-2+ cells

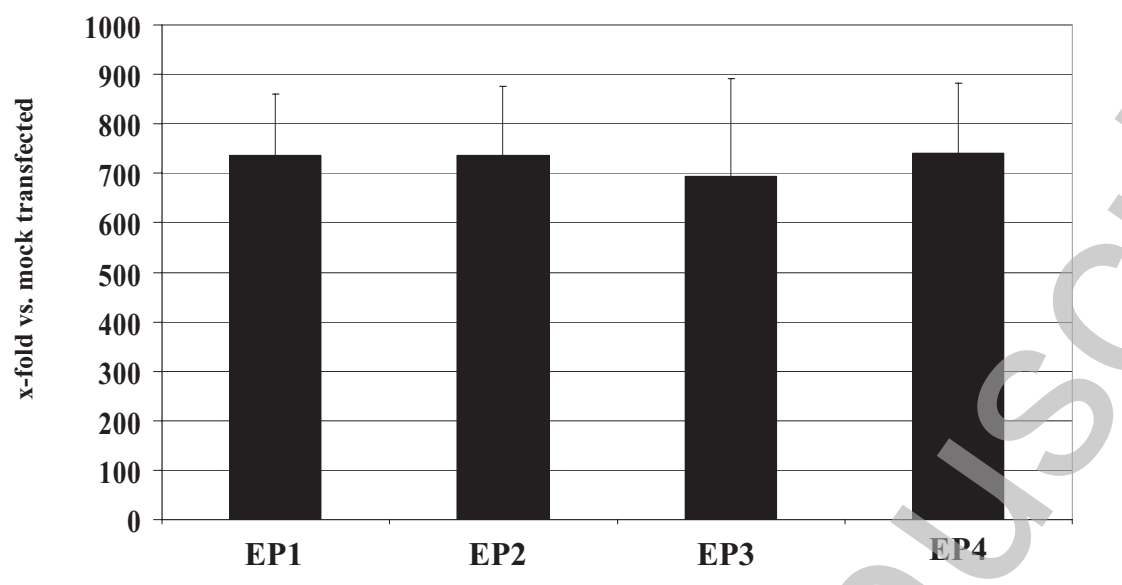

B:

EP receptor protein over-expression in COX-2+ cells

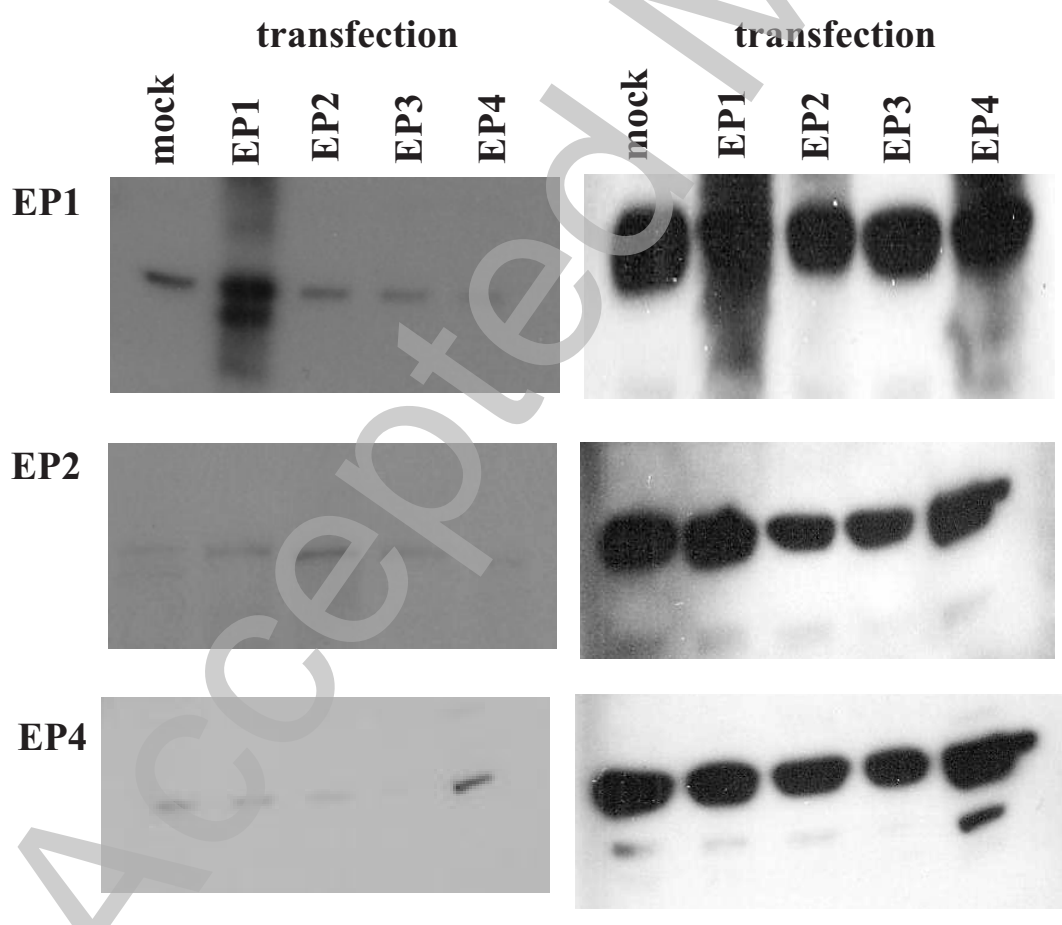

B-actin 


\section{Figure 4:}

CCL2 RNA expression in EP receptor-transfected COX-2+ cells A:

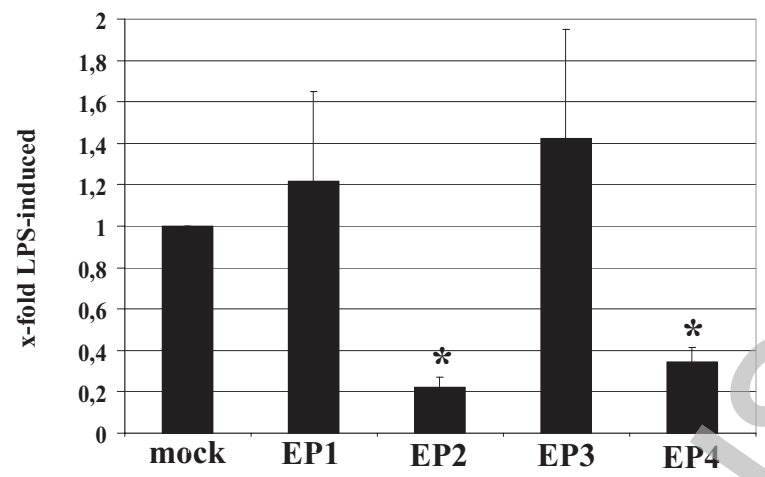

\section{CCL2 protein secretion in EP receptor-transfected COX-2+ cells}

B:

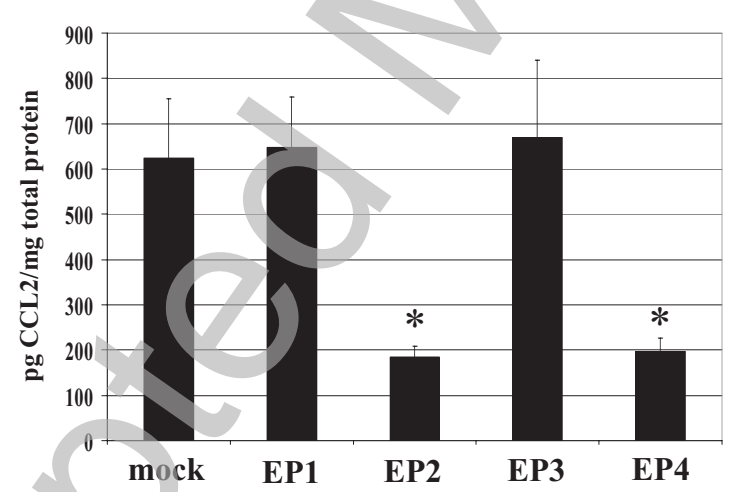

